Article

\title{
Downregulation of de Novo Fatty Acid Synthesis in Subcutaneous Adipose Tissue of Moderately Obese Women
}

\author{
Esther Guiu-Jurado ${ }^{1,+}$, Teresa Auguet ${ }^{1,2,+}$, Alba Berlanga ${ }^{1}$, Gemma Aragonès ${ }^{1}$, \\ Carmen Aguilar ${ }^{1}$, Fàtima Sabench ${ }^{3}$, Sandra Armengol ${ }^{1}$, José Antonio Porras ${ }^{2}$, Andreu Martí ${ }^{2}$, \\ Rosa Jorba ${ }^{4}$, Mercè Hernández ${ }^{3}$, Daniel del Castillo ${ }^{3}$ and Cristóbal Richart ${ }^{1,2, *}$
}

Received: 9 October 2015; Accepted: 4 December 2015; Published: 16 December 2015

Academic Editor: Toshiro Arai

1 Grup de Recerca GEMMAIR (AGAUR)-Medicina Aplicada, Departament de Medicina i Cirurgia, Universitat Rovira i Virgili (URV), Institut d'Investigació Pere Virgili (IISPV), Mallafré Guasch, 4, 43007 Tarragona, Spain; esther.guiu@urv.cat (E.G.-J.); tauguet.hj23.ics@gencat.cat (T.A.); alba.berlanga@urv.cat (A.B.); gemma.aragones@iispv.cat (G.A.); caguilar.hj23.ics@gencat.cat (C.A.); sandra.armengol@urv.cat (S.A.)

2 Servei Medicina Interna, Hospital Universitari Joan XXIII Tarragona, Mallafré Guasch, 4, 43007 Tarragona, Spain; aporras.hj23.ics@gencat.cat (J.A.P.); andreumano@gmail.com (A.M.)

3 Servei de Cirurgia, Hospital Sant Joan de Reus, Departament de Medicina i Cirurgia, Universitat Rovira i Virgili (URV), Institut d'Investigació Pere Virgili (IISPV), Avinguda Doctor Josep Laporte, 2, 43204 Reus, Spain; fatima.sabench@urv.cat (F.S.); mhernandezg@grupsagessa.com (M.H.); ddelcastillo@grupsagessa.com (D.C.)

4 Servei de Cirurgia, Hospital Universitari Joan XXIII Tarragona, Mallafré Guasch, 4, 43007 Tarragona, Spain; rjorba.hj23.ics@gencat.cat

* Correspondence: crichart.hj23.ics@gencat.cat; Tel./Fax: +34-977-295-833

+ These authors contributed equally to this work.

\begin{abstract}
The purpose of this work was to evaluate the expression of fatty acid metabolism-related genes in human adipose tissue from moderately obese women. We used qRT-PCR and Western Blot to analyze visceral (VAT) and subcutaneous (SAT) adipose tissue mRNA expression involved in de novo fatty acid synthesis (ACC1, FAS), fatty acid oxidation (PPAR $\alpha, P P A R \delta)$ and inflammation $(I L 6, T N F \alpha)$, in normal weight control women (BMI $\left.<25 \mathrm{~kg} / \mathrm{m}^{2}, n=35\right)$ and moderately obese women (BMI $30-38 \mathrm{~kg} / \mathrm{m}^{2}, n=55$ ). In SAT, ACC1, FAS and PPAR $\alpha$ mRNA expression were significantly decreased in moderately obese women compared to controls. The downregulation reported in SAT was more pronounced when BMI increased. In VAT, lipogenic-related genes and $P P A R \alpha$ were similar in both groups. Only PPAR $\delta$ gene expression was significantly increased in moderately obese women. As far as inflammation is concerned, TNF $\alpha$ and IL6 were significantly increased in moderate obesity in both tissues. Our results indicate that there is a progressive downregulation in lipogenesis in SAT as BMI increases, which suggests that SAT decreases the synthesis of fatty acid de novo during the development of obesity, whereas in VAT lipogenesis remains active regardless of the degree of obesity.
\end{abstract}

Keywords: moderate obesity; fatty acid metabolism; adipose tissue; de novo fatty acid synthesis

\section{Introduction}

Obesity is significantly associated with the development of several comorbidities including type 2 diabetes mellitus, dyslipidemia, hypertension, metabolic syndrome, non-alcoholic fatty liver disease, cardiovascular disease and certain neoplasms [1]. Nevertheless, obesity itself does not necessarily lead to these comorbidities [2-4]. 
Not only fat accumulation in ectopic sites but also dysfunction of adipose tissue might play a significant role in defining an individual's risk of developing obesity-related comorbidities [5]. Physiological and molecular studies have suggested that the fat stored in subcutaneous adipose depots are not directly implicated in the development of insulin resistance. It seems to have a "buffering" role due to the fact that it takes up fatty acids (FAs) and prevents other insulin-sensitive tissues from being exposed to their damaging consequences [6]. In this sense, Klein et al. showed that obesity-associated metabolic variables were not improved by liposuction (reduction of subcutaneous adipose tissue) [7]. However, reducing visceral adipose tissue by omentectomy combined with gastric banding has positive long-term effects on insulin sensitivity and glucose metabolism [8].

Likewise, deregulation of lipogenesis and FA oxidation contribute to the development of metabolic diseases [9]. The expression of de novo FA synthesis enzymes in human adipose tissue have been evaluated in some studies that have found lower mRNA expression in obese patients compared to control subjects [10-15]. With regard to FA oxidation, several reports have shown that activating the peroxisome proliferator-activated receptor aplha (PPAR $\alpha)$ in human adipocytes enhanced FA oxidation by inducing the mRNA expression of the genes involved in this pathway [16,17]. Moreover, Wang et al. showed that targeted activation of peroxisome proliferator-activated receptor delta (PPAR $\delta$ ) in adipose tissue induces FA oxidation gene expression [18].

In a previous work, we studied the expression of the main genes involved in fatty acid metabolism in adipose tissue of morbidly obese and normal-weight control women [19]. Our findings suggested that, in morbid obesity, SAT prevents the subcutaneous fat mass from developing further. Because not all obese subjects have the same metabolic traits and the mechanisms of adipose tissue dysfunction are not fully understood, the aim of the present study was to use our previous findings to investigate whether the alterations in the fatty acid metabolism of morbidly obese women also manifest in moderately obese women. Consequently, we evaluated the expression of key genes related to de novo synthesis of FAs $(A C C 1, F A S)$, FA oxidation $(P P A R \delta, P P A R \alpha)$ and inflammation $(I L 6, T N F \alpha)$ in the SAT and VAT of moderately obese and normal-weight control women.

\section{Results}

\subsection{Baseline Characteristics of the Cohort Studied}

Subjects were classified according to BMI into control (BMI $<25 \mathrm{~kg} / \mathrm{m}^{2}$ ), and moderately obese patients (BMI 30-38 kg/m²). The patients' baseline characteristics are shown in Table 1. Moderately obese women had significantly higher levels of glucose metabolism variables (fasting glucose, insulin, $\mathrm{HbA} 1 \mathrm{c}$ and HOMA2-IR) and triglycerides than the control group. HDL-C was significantly decreased in the moderately obese compared to controls.

Subsequently we sub-classified the moderately obese women according to the presence of diabetes. Obviously, the results indicate that glucose and $\mathrm{HbA1c}$ were significantly increased in diabetic patients (D) compared to non-diabetic subjects (ND) (Glucose: ND $=93.67 \pm 2.73$, $\mathrm{D}=172.56 \pm 21.58 \mathrm{mg} / \mathrm{dL}, p<0.001 ; \mathrm{HbA1}: \mathrm{ND}=5.22 \pm 1.83, \mathrm{D}=7.16 \pm 1.83, p=0.030)$.

Table 1. Characteristics of the cohort studied.

\begin{tabular}{cccc}
\hline \multirow{2}{*}{ Variables } & Controls $(\boldsymbol{n = 3 5 )}$ & $\begin{array}{c}\text { Moderately Obese } \\
\text { Patients }(\boldsymbol{n}=\mathbf{5 5})\end{array}$ & $\boldsymbol{p}$-Value \\
\cline { 2 - 3 } & Mean \pm SD & Mean \pm SD & \\
\hline AGE (years) & $49.57 \pm 14.17$ & $52.94 \pm 14.24$ & 0.289 \\
WEIGHT (kg) & $57.53 \pm 7.17$ & $84.49 \pm 11.65$ & $<\mathbf{0 . 0 0 1}$ \\
WC $(\mathrm{cm})$ & $76.43 \pm 11.42$ & $109.85 \pm 11.15$ & $<\mathbf{0 0 1}$ \\
BMI $\left(\mathrm{kg} / \mathrm{m}^{2}\right)$ & $22.28 \pm 1.63$ & $33.67 \pm 2.70$ & $<\mathbf{0 . 0 0 1}$ \\
GLUCOSE $(\mathrm{mg} / \mathrm{dL})$ & $86.51 \pm 22.96$ & $110.61 \pm 45.32$ & $\mathbf{0 . 0 0 2}$ \\
INSULIN (mU/L) & $6.84 \pm 5.43$ & $13.88 \pm 9.65$ & $<\mathbf{0 . 0 0 1}$ \\
HbA1c (\%) & $4.92 \pm 0.64$ & $5.49 \pm 1.18$ & $\mathbf{0 . 0 1 5}$ \\
\hline
\end{tabular}


Table 1. Cont.

\begin{tabular}{cccc}
\hline \multirow{2}{*}{ Variables } & Controls $(\boldsymbol{n = 3 5 )}$ & $\begin{array}{c}\text { Moderately Obese } \\
\text { Patients }(\boldsymbol{n}=\mathbf{5 5})\end{array}$ & \multirow{2}{*}{-Value } \\
\cline { 2 - 3 } & Mean \pm SD & Mean \pm SD & \\
\hline HOMA2-IR & $0.88 \pm 0.75$ & $1.90 \pm 1.38$ & $<\mathbf{0 . 0 0 1}$ \\
SBP $(\mathrm{mmHg})$ & $124.63 \pm 18.20$ & $130.37 \pm 18.11$ & 0.157 \\
DBP $(\mathrm{mmHg})$ & $69.8 \pm 9.52$ & $74.27 \pm 11.45$ & 0.063 \\
TOTAL CHOLESTEROL $(\mathrm{mg} / \mathrm{dL})$ & $181.33 \pm 37.57$ & $182.92 \pm 51.38$ & 0.867 \\
HDL-C $(\mathrm{mg} / \mathrm{dL})$ & $55.34 \pm 14.93$ & $43.29 \pm 10.86$ & $<\mathbf{0 . 0 0 1}$ \\
TRIGLYCERIDES $(\mathrm{mg} / \mathrm{dL})$ & $107.33 \pm 31.02$ & $113.6 \pm 43.37$ & 0.482 \\
\hline
\end{tabular}

$p$-Values in bold indicate significant differences with respect to the control group $(p<0.05)$. BMI, body mass index; DBP, diastolic blood pressure; HbA1c, glycated haemoglobin; HDL-C, high-density lipoprotein; HOMA2-IR, homeostatic model assessment 2-insulin resistance; LDL-C, low-density lipoprotein; SBP, systolic blood pressure; WC, waist circumference.

\subsection{Evaluation of the Expression of FA Metabolism Genes and Their Protein Levels in SAT and VAT}

We performed the expression analysis of genes related to lipogenesis (ACC1, FAS), FA oxidation $(P P A R \alpha, P P A R \delta)$ and inflammation (IL6, TNF $\alpha)$ in human adipose tissue.

To investigate how gene expression was affected by BMI, we conducted analyses in the controls $\left(\right.$ BMI $<25 \mathrm{~kg} / \mathrm{m}^{2}$ ) and moderately obese women (BMI $30-38 \mathrm{~kg} / \mathrm{m}^{2}$ ). The subcutaneous mRNA expression of genes related to lipogenesis was significantly decreased in moderately obese women compared to control women (Figure 1). The results for VAT indicate that ACC1 and FAS mRNA expression were similar in both groups (Figure 2). To validate these results, we also conducted Western Blot analysis of ACC1 and FAS in both fat depots. The protein analysis showed that ACC1 and FAS protein levels were similar to those obtained in the mRNA expression analysis. ACC1 and FAS protein levels in SAT were significantly lower in moderately obese patients (Figure 3A), whereas in VAT there were no differences between the two groups (Figure 3B).
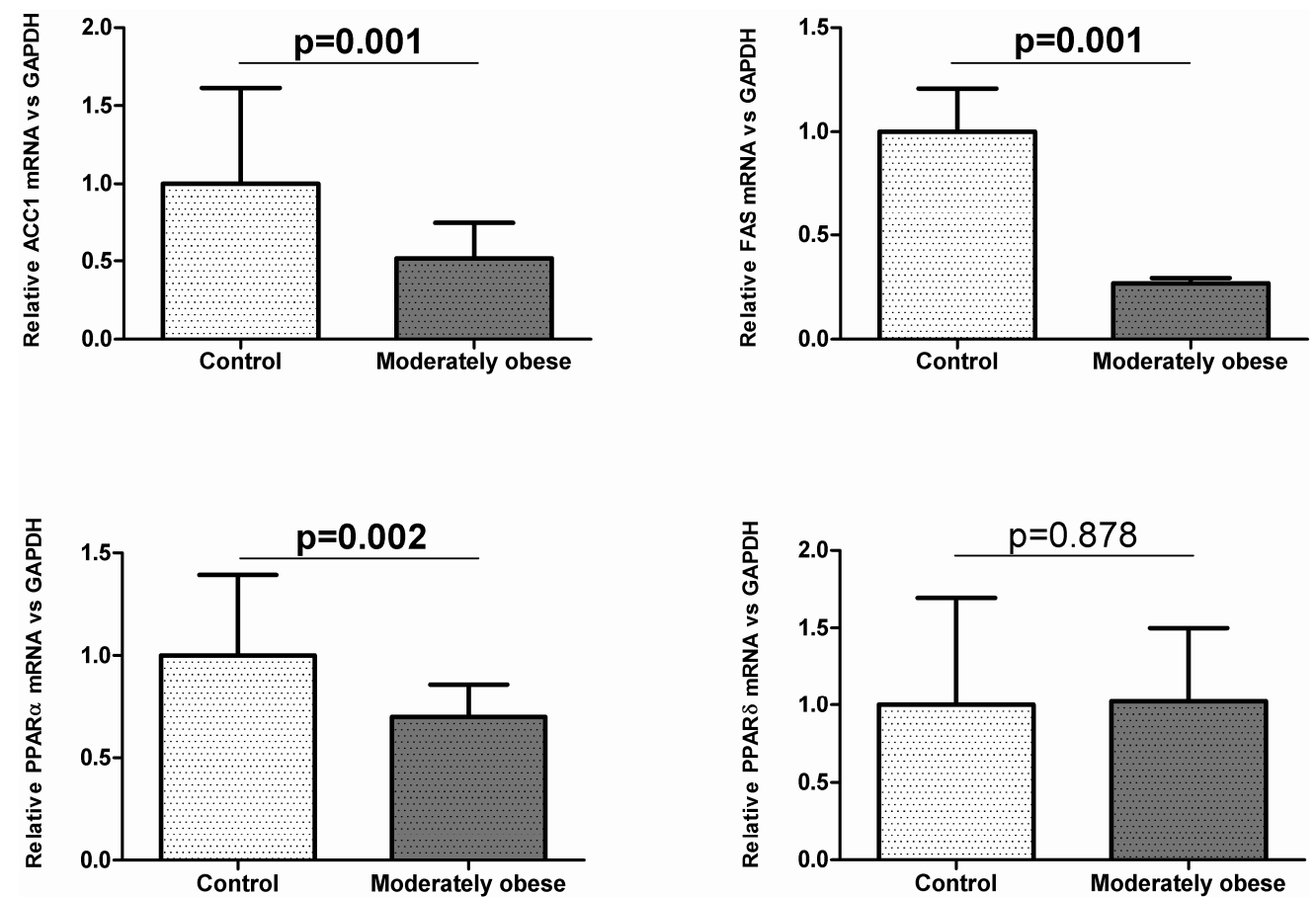

Figure 1. Cont. 

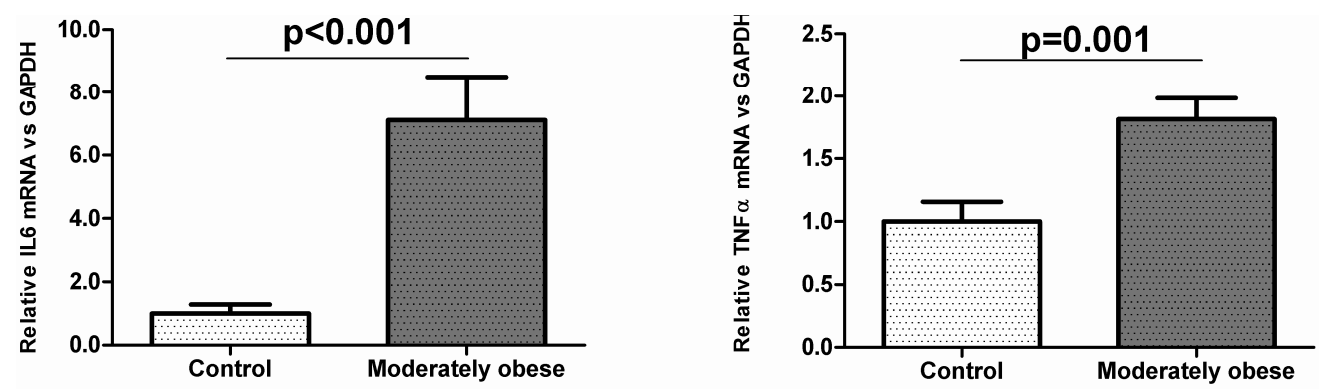

Figure 1. Expression of genes involved in lipogenesis, FA oxidation and inflammation in control $(n=35)$ and moderately obese women $(n=55)$ in subcutaneous adipose tissue. Student's $t$-test was used to determinate differences between groups. Data are expressed as mean \pm SD. The mRNA expression was calculated relative to the control group, whose mRNA expression was set to 1.0. ACC1, Acetyl-CoA carboxylase 1; FAS, Fatty acid synthase; IL6, Interleukin 6; PPAR $\alpha$, Peroxisome proliferator-activated receptor alpha; PPAR $\delta$, Peroxisome proliferator-activated receptor delta; TNF $\alpha$, Tumor necrosis factor alpha.
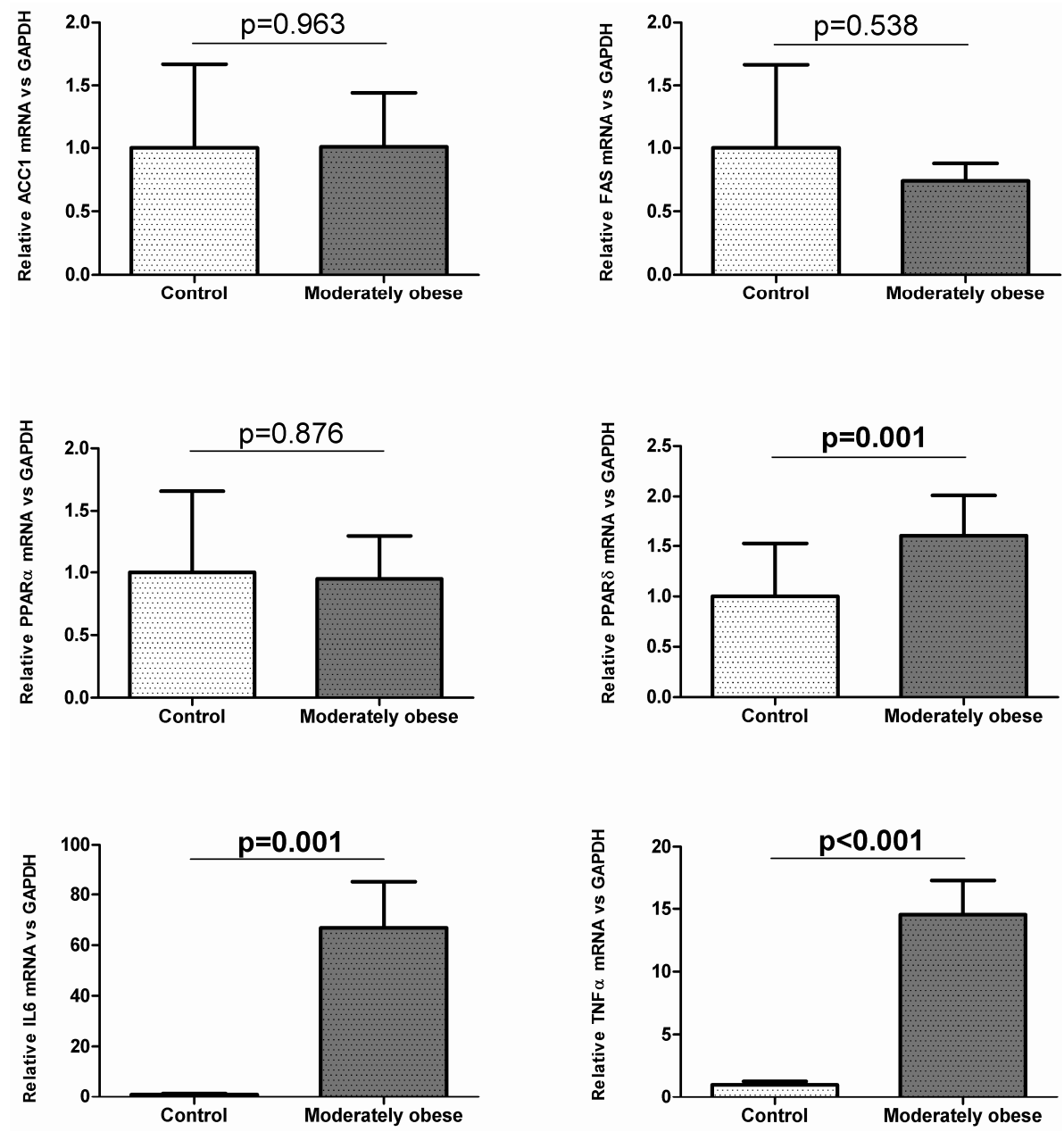

Figure 2. Expression of genes related to lipogenesis, FA oxidation and inflammation in control $(n=35)$ and moderately obese women $(n=55)$ in visceral adipose tissue. Student's $t$-test was used to determinate differences between groups. Data are expressed as mean \pm SD. The mRNA expression was calculated relative to the control group, whose mRNA expression was set to 1.0. ACC1, Acetyl-CoA carboxylase 1; FAS, Fatty acid synthase; IL6, Interleukin 6; PPAR $\alpha$, Peroxisome proliferator-activated receptor alpha; PPAR $\delta$, Peroxisome proliferator-activated receptor delta; TNF $\alpha$, Tumor necrosis factor alpha. 
A

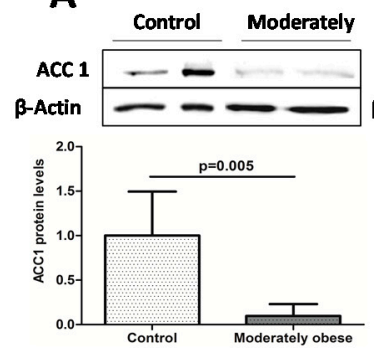

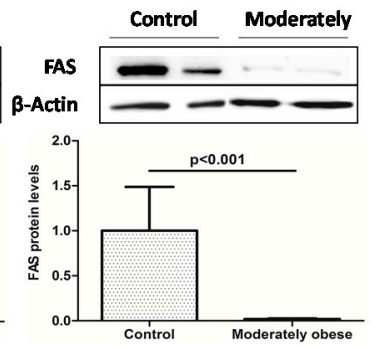
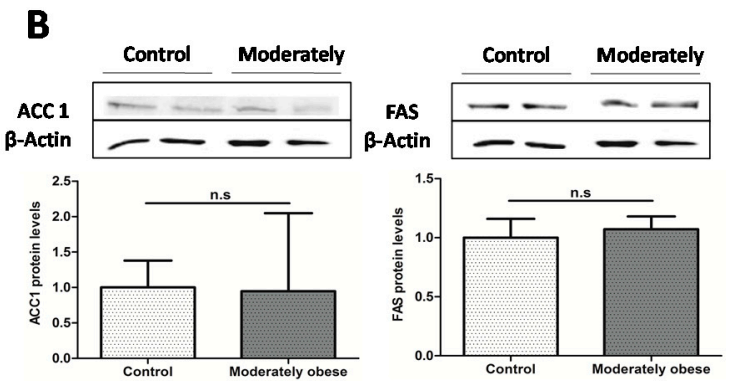

Figure 3. Western blot analysis of the main lipogenic enzymes in subcutaneous (A); and visceral (B) adipose tissue of moderately obese patients. Bar graphs show the quantification of ACC1 and FAS bands normalized by values of $\beta$-actin ( $n=12$ for each group). Student's $t$-test was used to determinate differences between groups. Data are expressed as mean \pm SD. ACC1, Acetyl-CoA carboxylase 1; FAS, Fatty acid synthase.

In relation to the FA oxidation genes, our findings showed that visceral PPAR $\delta$ gene expression was significantly higher in moderately obese women than in controls (Figure 2), while subcutaneous mRNA expression was not significantly different in both groups (Figure 1). The subcutaneous mRNA expression of PPAR $\alpha$ was significantly lower in moderately obese women (Figure 1), whereas in VAT, $P P A R \alpha$ gene expression was similar in the two groups studied (Figure 2).

Regarding inflammation genes, the results showed that IL6 and TNF $\alpha$ gene expression were significantly increased in the moderately obese women compared to control women in both tissues (Figures 1 and 2).

Finally, the comparison of the mRNA expression of lipogenic and oxidative genes between moderately obese women and the morbidly obese women studied elsewhere [19] showed that the expression of the genes related to lipogenesis $(A C C 1, F A S)$ and FA oxidation $(P P A R \alpha, P P A R \delta)$ was significantly lower in morbidly obese women than in moderately obese women in the SAT depot $(p<0.001)$. In the VAT depot, ACC1 mRNA expression was downregulated in morbidly obese women $(p=0.013)$, while FAS gene expression was not significantly different in both types of obesity $(p=0.080)$. With regard to FA oxidation, PPAR $\delta$ mRNA expression was lower in morbidly obese women than in moderately obese women $(p<0.001)$, whereas PPAR $\alpha$ mRNA expression was similar in both groups $(p=0.124)$.

\subsection{Correlation of VAT and SAT mRNA Expression with Parameters of Obesity and Glucose Metabolism}

In VAT, we found that the oxidative gene PPAR $\delta$ correlated positively with BMI, weight and waist circumference (WC) (Table 2). PPAR $\alpha$ mRNA expression correlated negatively with HOMA2-IR (Table 2). On the contrary, IL6 and TNF $\alpha$ gene expression correlated positively with HOMA2-IR, insulin, glucose and HbA1c (Table 2).

In SAT, we found that FAS mRNA expression has negative correlations with weight, BMI, WC, glucose, insulin and HOMA2-IR (Table 3). One of the key enzymes in lipogenesis, ACC1, correlated negatively with weight and BMI (Table 3). Also, our findings showed negative correlations between $P P A R \alpha$ expression and weight, BMI and WC (Table 3). Furthermore, PPAR $\delta$ correlated positively with $\mathrm{HbA1c}$ (Table 3). For the genes involved in inflammation, we found that IL6 mRNA expression has positive correlations with weight, BMI, WC, glucose, insulin and HOMA2-IR (Table 3). TNF $\alpha$ gene expression also correlated positively with weight, BMI, WC, insulin and HOMA2-IR (Table 3). 
Table 2. Correlations of visceral mRNA expression of genes involved in fatty acid metabolism and inflammation with anthropometric and glucose metabolism parameters.

\begin{tabular}{|c|c|c|c|c|c|c|c|c|c|c|c|c|}
\hline \multirow{2}{*}{ Variables } & \multicolumn{2}{|c|}{$A C C 1$} & \multicolumn{2}{|c|}{$F A S$} & \multicolumn{2}{|c|}{ PPAR $\alpha$} & \multicolumn{2}{|c|}{ PPARS } & \multicolumn{2}{|c|}{ IL6 } & \multicolumn{2}{|c|}{$T N F \alpha$} \\
\hline & $r$ & $p$-Value & $r$ & $p$-Value & $r$ & $p$-Value & $r$ & $p$-Value & $r$ & $p$-Value & $r$ & $p$-Value \\
\hline WEIGHT (kg) & -0.044 & 0.797 & -0.010 & 0.957 & -0.141 & 0.464 & 0.387 & 0.018 & 0.430 & 0.020 & 0.214 & 0.275 \\
\hline WC $(\mathrm{cm})$ & 0.196 & 0.521 & 0.291 & 0.335 & -0.314 & 0.320 & 0.527 & 0.044 & 0.243 & 0.447 & 0.179 & 0.597 \\
\hline $\operatorname{BMI}\left(\mathrm{kg} / \mathrm{m}^{2}\right)$ & -0.027 & 0.874 & -0.044 & 0.812 & -0.146 & 0.450 & 0.464 & 0.004 & 0.459 & 0.012 & 0.351 & 0.067 \\
\hline GLUCOSE (mg/dL) & -0.122 & 0.487 & -0.153 & 0.411 & -0.261 & 0.180 & 0.136 & 0.423 & 0.573 & 0.001 & 0.533 & 0.004 \\
\hline INSULIN (mU/L) & -0.045 & 0.808 & -0.251 & 0.198 & 0.375 & 0.065 & 0.041 & 0.816 & 0.374 & 0.046 & 0.526 & 0.007 \\
\hline $\mathrm{HbA1c}(\%)$ & 0.105 & 0.587 & -0.212 & 0.298 & -0.031 & 0.887 & 0.221 & 0.233 & 0.496 & 0.002 & 0.427 & 0.042 \\
\hline HOMA2-IR & -0.087 & 0.642 & -0.279 & 0.158 & -0.418 & 0.042 & 0.062 & 0.730 & 0.479 & 0.009 & 0.558 & 0.004 \\
\hline
\end{tabular}

BMI, body mass index; HbA1c, glycated haemoglobin; HOMA2-IR, homeostatic model assessment 2-insulin resistance; WC, waist circumference. The strength of association between variables was calculated using Pearson's $r$ correlation test. Bold numbers indicate statistically significant correlations $(p$-value $<0.05)$.

Table 3. Correlations of subcutaneous mRNA expression of genes involved in fatty acid metabolism and inflammation with anthropometric and glucose metabolism parameters.

\begin{tabular}{|c|c|c|c|c|c|c|c|c|c|c|c|c|}
\hline \multirow{2}{*}{ Variables } & \multicolumn{2}{|c|}{$A C C 1$} & \multicolumn{2}{|c|}{ FAS } & \multicolumn{2}{|c|}{ PPAR $\alpha$} & \multicolumn{2}{|c|}{ PPARS } & \multicolumn{2}{|c|}{ IL6 } & \multicolumn{2}{|c|}{$T N F \alpha$} \\
\hline & $r$ & $p$-Value & $r$ & $p$-Value & $r$ & $p$-Value & $r$ & $p$-Value & $r$ & $p$-Value & $r$ & $p$-Value \\
\hline WEIGHT (kg) & -0.483 & $<0.001$ & -0.429 & $<0.001$ & -0.369 & 0.003 & -0.002 & 0.990 & 0.488 & $<0.001$ & 0.247 & 0.030 \\
\hline $\mathrm{WC}(\mathrm{cm})$ & -0.366 & 0.072 & -0.388 & 0.031 & -0.475 & 0.026 & 0.162 & 0.400 & 0.451 & 0.018 & 0.493 & 0.005 \\
\hline $\operatorname{BMI}\left(\mathrm{kg} / \mathrm{m}^{2}\right)$ & -0.526 & $<0.001$ & -0.496 & $<0.001$ & -0.483 & $<0.001$ & 0.000 & 0.998 & 0.449 & $<0.001$ & 0.269 & 0.018 \\
\hline GLUCOSE (mg/dL) & -0.192 & 0.108 & -0.240 & 0.022 & -0.205 & 0.116 & 0.074 & 0.527 & 0.244 & 0.040 & 0.048 & 0.684 \\
\hline INSULIN (mU/L) & -0.216 & 0.081 & -0.298 & 0.013 & -0.180 & 0.185 & 0.182 & 0.132 & 0.275 & 0.028 & 0.264 & 0.028 \\
\hline $\mathrm{HbA1c}(\%)$ & -0.042 & 0.750 & -0.076 & 0.562 & -0.127 & 0.367 & 0.264 & 0.034 & 0.107 & 0.428 & 0.147 & 0.257 \\
\hline HOMA2-IR & -0.216 & 0.082 & -0.297 & 0.013 & -0.183 & 0.177 & 0.188 & 0.120 & 0.341 & 0.006 & 0.238 & 0.049 \\
\hline
\end{tabular}

BMI, body mass index; HbA1c, glycated haemoglobin; HOMA2-IR, homeostatic model assessment 2-insulin resistance; WC, waist circumference. The strength of association between variables was calculated using Pearson's $r$ correlation test. Bold numbers indicate statistically significant correlations $(p$-value $<0.05)$. 


\subsection{Relationship between the mRNA Expression of Genes Involved in Lipogenesis, FA Oxidation and Inflammation in VAT and SAT}

The associations between the expression of the genes involved in lipogenesis point out that FAS mRNA expression was directly related to ACC1 mRNA expression in both VAT and SAT depots (SAT: $r=0.822, p<0.001$; VAT: $r=0.417, p=0.018$ ). In regard to FA oxidation correlation analysis, the findings showed that PPAR $\alpha$ and PPAR $\delta$ mNA expression were not related in both fat tissues. Finally, IL6 gene expression had a positive correlation with TNF $\alpha$ gene expression in both tissues (SAT: $r=0.314, p=0.004$; VAT: $r=0.342, p=0.05$ ).

\section{Discussion}

In the present work, we investigated the expression of crucial genes in fatty acid metabolism in VAT and SAT paired samples from moderately obese and normal-weight women. Although some studies of fatty acid metabolism in human adipose tissue have been published [10,12-14,20,21], the originality of the present work resides in the fact that it provides a validated study of fatty acid metabolism in both adipose tissues simultaneously in moderate obesity.

The main findings of this work show that the gene expression of the main enzymes related to de novo fatty acid synthesis (ACC1, FAS) and PPAR $\alpha$ was similar in the two groups in VAT, but different in SAT. Their subcutaneous mRNA expression was significantly downregulated in moderately obese women.

It should also be noted that when the mRNA expression of these genes in moderately obese women was compared to the expression in morbidly obese women studied elsewhere [19], we found that the subcutaneous mRNA expression of all the genes studied was lower in morbidly obese women; that is to say, mRNA expression decreases when BMI increases.

In our study, the lipogenic pathway is, at mRNA and protein expression levels, downregulated in the subcutaneous fat depot of moderately obese women. Although an increase of de novo FA synthesis is expected in the development of obesity, our findings agree with those of other authors [22,23]. They indicate that the downregulation of the lipogenesis pathway in the obese cohort is a late and adaptive process that prevents the fat mass from developing further. In this sense, mice lacking the lipogenic enzyme FAS in adipose tissue manifested resistance to diet-induced obesity and increased energy expenditure. Also, Lodhi et al. found a decreased adipogenesis activity in FAS knockdown embryonic fibroblasts [24].

As far as the expression of genes related to FA oxidation was concerned, our results showed that in SAT PPAR gene expression was similar in the two groups studied, whereas in VAT it was upregulated in moderately obese women. In SAT PPAR $\alpha$ gene expression was downregulated, while in VAT it was similar in the two groups. The decreased FA oxidation in SAT in moderately obese women might be explained, at least in part, because mitochondrial function-related genes are downregulated in male and female obese subjects [25]. Moreover, in morbidly obese patients, MacLaren et al. found an increase in lipid storage and lipolytic genes, but a decrease in de novo triglyceride synthesis and oxidative genes in SAT [26]. The role of these PPARs in white adipose tissue in the pathophysiology of obesity has yet to be elucidated. New prospective studies are needed to clarify their function in obese adipocytes.

Besides the processes described above, there are also others involved in fat accumulation in white adipose tissue such as FA uptake or lipolysis. It is important to note, that all these processes, occur at different rates and amounts in obese and normal-weight individuals, depending upon the anatomical location of the adipose tissue, and also according to gender and grade of obesity [27].

It is well known that the increased IL6 and TNF $\alpha$ circulating levels in obese patients have led to the conclusion that obesity is characterized by a subjacent chronic low-grade inflammation [28]. In this sense, our results showed increased IL6 and TNF $\alpha$ gene expression in moderately obese women in comparison with the control group in both tissues. 
Our results reinforce the hypothesis that SAT, from a metabolic point of view, is less harmful than VAT [29]. Recent studies have analyzed whether subcutaneous, intra-abdominal and hepatic fat were related to insulin resistance and lipidic parameters. Only subcutaneous fat was not significantly correlated to these variables [30]. In vitro and in vivo studies of the physiology of adipose tissue confirm that lipolysis and fatty acid uptake rates are not the same in SAT as in VAT. SAT appears to be more passive than VAT and to limit the detrimental effects of ectopic fat deposition by the long-term accumulation of excess FAs [6]. Also, subcutaneous fat is related to a favorable adipokine profile [6]. In this respect, individuals with Cushing's syndrome or congenital lipodystrophies tend to have increased metabolic and cardiovascular risk despite having a marked reduction in subcutaneous fat [31,32]. Moreover, several reports have shown that regional subcutaneous fat mass is inversely associated with fasting insulin levels and insulin levels after an oral glucose load, and positively associated with insulin sensitivity [33-36]. In agreement with these results, we found that FAS mRNA expression is inversely associated with insulin, glucose and HOMA2-IR. Data on the beneficial metabolic consequences of SAT, the deleterious effects of its deficiency $[37,38]$ and the positive effects of its transplantation into VAT depots in mice [39] suggests that SAT plays a "buffering" role in obesity due to the fact that it prevents excess supply of lipids from spilling over into "ectopic" sites [40].

Our study cohort allowed us to investigate lipogenic and FA oxidation pathways in SAT and VAT fat depots without the interference of confounding factors like gender or age. Only women were included because it is well known that men and women differ substantially in regard to body composition, energy imbalance, sex hormones and adipokines [41,42]. Moreover, several studies showed sex-specific differences in lipid and glucose metabolism [43]. We were also able to extrapolate the results found in the morbidly obese cohort [19] to the moderately obese cohort. Nevertheless, the results of our study cannot be extrapolated to men.

\section{Material and Methods}

\subsection{Subjects}

The study was approved by the ethics committee of the Hospital Sant Joan de Reus and all subjects gave written informed consent before taking part in the study. The majority of the patients in the Hospital Sant Joan de Reus who undergo bariatric surgery or laparoscopic cholecystectomy are women. Therefore, adipose tissue samples were from 105 Caucasian women. Of these, 55 were moderately obese (body mass index (BMI) $30-38 \mathrm{~kg} / \mathrm{m}^{2}$ ) and 35 were normal-weight controls $\left(\right.$ BMI $\left.<25 \mathrm{~kg} / \mathrm{m}^{2}\right)$. SAT and VAT samples were obtained from moderately obese patients who had undergone bariatric surgery (patients with BMI $\geqslant 37 \mathrm{~kg} / \mathrm{m}^{2}$ ) and laparoscopic cholecystectomy for benign gall bladder disease or laparoscopic hiatus hernia repair (patients with BMI $<37 \mathrm{~kg} / \mathrm{m}^{2}$ ) and from normal-weight subjects who had undergone laparoscopic abdominal surgery (described in detail elsewhere) [19].

The moderately obese and normal-weight women were of similar ages. The body weight of the moderately obese group had not fluctuated be more than $2 \%$ for at least three months before surgery. The exclusion criteria were: (1) patients who were taken antidiabetic or hypolipemiant drugs; (2) diabetic women receiving insulin; (3) subjects undergoing contraceptive treatment; (4) patients who had an acute illness, inflammatory or infectious diseases or neoplastic malignant diseases.

Of the moderately obese women, $16 \%$ were diagnosed with type 2 diabetes mellitus based on ADA guidelines [44]. These patients were following a dietetic treatment. All the usual exclusion criteria were taken into account.

\subsection{Biochemical Analyses}

Each of our patients was evaluated with a complete physical, anthropometrical and biochemical assessment. Total cholesterol, HDL-C, LDL-C, triglycerides, glucose, insulin and $\mathrm{HbA1c}$ were 
measured using a conventional automated analyzer after overnight fasting. Insulin resistance (IR) was calculated using HOMA2-IR [45].

\subsection{RNA Isolation and Gene Expression}

Total RNA was extracted from SAT and VAT by using the RNeasy mini kit (Qiagen, Barcelona, Spain) and was reverse transcribed to cDNA using the High Capacity RNA-to-cDNA Kit (Applied Biosystems, Madrid, Spain). Real-time quantitative PCR was carried out with TaqMan Assay predesigned by Applied Biosystems for the detection of ACC1, FAS, PPAR $\alpha, P P A R \delta$, IL6, TNF $\alpha$ and GAPDH gene. All reactions were performed in duplicate using the 7900HT Fast Real-Time PCR systems. SAT and VAT mRNA expression of the genes mentioned above was calculated relative to the mRNA expression of Glyceraldehyde-3-Phosphate Dehydrogenase (GAPDH).

\subsection{Western Analysis}

Protein levels of ACC1 and FAS were assayed by Western Blot. Frozen SAT and VAT tissue samples from 24 individuals (MO, $n=12$; Control, $n=12$ ) were homogenized in lysis buffer (50 mM HEPES, $150 \mathrm{mM} \mathrm{NaCl}, 1 \mathrm{mM}$ EDTA, $1 \mathrm{mM}$ DTT, 0.1\% SDS, $100 \mathrm{mM} \mathrm{NaF}, 30 \mathrm{mM} \mathrm{Na} \mathrm{O}_{7} \mathrm{P}_{2}$ and $1 \%$ protease inhibitor cocktail (Thermo Scientific, Madrid, Spain)). Protein concentration was determined using BCA assay kit (Thermo Scientific). Samples were separated by SDS/PAGE and transferred electrophoretically to nylon membranes. Membranes were blocked by incubation in a solution of $5 \%$ skimmed milk and were probed using antibodies against ACC1, FAS and $\beta$-actin (Cell Signaling, Danvers, MA, USA). Anti-rabbit IgG or anti-mouse IgG (Thermo Scientific) were used as secondary antibody. Immunodetection of the protein was done using SuperSignal West Pico or Femto Chemiluminescent kit (Thermo Scientific). Finally, band densitometry was analyzed using Phoretix1D software.

\subsection{Statistical Analyses}

Results are expressed as mean \pm SD (standard deviation). Student's $t$-test or one-way ANOVA were carried out to determinate differences between groups. Univariate association was tested by Pearson (parametric variables) or Spearman (nonparametric variables) correlation analysis. We used SPSS/PC+ statistical package (version 22.0; SPSS, Chicago, IL, USA) for the statistical analyses. $p$-values $<0.05$ were considered statistically significant.

\section{Conclusions}

The results reported here suggest that, in moderate obesity, subcutaneous fat has a defense mechanism against an excess of fatty acid accumulation by diminishing the expression of lipogenic-related genes, while visceral fat does not. Interestingly, the extrapolation of the results found in the morbidly obese cohort [19] to the moderately obese cohort showed that this downregulation reported in subcutaneous adipose tissue increases as BMI increases. As far as FA oxidation is concerned, future studies are necessary to gain further knowledge about PPARs regulation in white adipose tissue of obese subjects.

Acknowledgments: This study was supported by the Ministerio de Ciencia e Innovación of the government of Spain (grant number SAF 2008-02278, to Cristóbal Richart), the Fondo de Investigación Sanitaria (grant number PI13/0468, to Teresa Auguet), by funds from Agència de Gestió d'Ajuts Universitaris de Recerca (AGAUR 2009 SGR 959 to Cristóbal Richart), Grup de Recerca en Medicina Aplicada URV (2010PFR-URV-B2-14 to C.R) and by the Fundación Biociencia.

Author Contributions: Esther Guiu-Jurado and Teresa Auguet participated in the design of the study, in the analysis and interpretation of data, and in drafting the manuscript; Alba Berlanga, Esther Guiu-Jurado, Sandra Armengol and Carmen Aguilar carried out the genetic and protein molecular studies and the immunoassays; Gemma Aragonès performed the statistical analysis; José Antonio Porras, Rosa Jorba, Fàtima Sabench, Andreu Marti and Mercè Hernàndez made substantial contributions to the conception and 
design of the study, and to the acquisition of samples; Daniel del Castillo and Cristóbal Richart revised the draft and gave final approval for publication.

Conflicts of Interest: The authors declare no conflict of interest.

\section{Abbreviations}

ACC1, acetyl-coenzyme A carboxylase 1; BMI, body mass index; DM2, diabetes mellitus type 2; FA, fatty acid; FAS, fatty acid synthase; GAPDH, glyceraldehyde-3-phosphate dehydrogenase; HbA1c, glycated haemoglobin; HDL-C, high density lipoprotein cholesterol; HOMA2-IR, homeostatic model assessment method insulin resistance; IL6, interleukin 6; IR, insulin resistance; LDL-C, low density lipoprotein cholesterol; $\operatorname{PPAR} \alpha$, peroxisome proliferator-activated receptor $\alpha$; PPAR $\delta$, peroxisome proliferator-activated receptor $\delta$; PPAR $\gamma$, peroxisome proliferator-activated receptor $\gamma$; SAT, subcutaneous adipose tissue, TNF $\alpha$, tumor necrosis factor; VAT, visceral adipose tissue; WC, waist circumference.

\section{References}

1. Lean, M.E. Pathophysiology of obesity. Proc. Nutr. Soc. 2000, 59, 331-336. [CrossRef] [PubMed]

2. Reaven, G.M. Perspective importance of identifying the overweight patient who will benefit the most by losing weight. Ann. Intern. Med. 2003, 138, 420-423. [CrossRef] [PubMed]

3. Klöting, N.; Fasshauer, M.; Dietrich, A.; Kovacs, P.; Schön, M.R.; Kern, M.; Stumvoll, M.; Blüher, M. Insulin-sensitive obesity. Am. J. Physiol. Endocrinol. Metab. 2010, 299, 506-515. [CrossRef] [PubMed]

4. Stefan, N.; Kantartzis, K.; Machann, J.; Schick, F.; Thamer, C.; Ritting, K.; Balletshofer, B.; Machicao, F.; Fritsche, A.; Häring, H.U. Identification and characterization of metabolically benign obesity in humans. Arch. Intern. Med. 2008, 168, 1609-1616. [CrossRef] [PubMed]

5. Blüher, M. Adipose tissue dysfunction contributes to obesity related metabolic diseases. Best Pract. Res. Clin. Endocrinol. Metab. 2013, 27, 163-177. [CrossRef] [PubMed]

6. Manolopoulos, K.N.; Karpe, F.; Frayn, K.N. Gluteofemoral body fat as a determinant of metabolic health. Int. J. Obes. 2010, 34, 949-959. [CrossRef] [PubMed]

7. Klein, S.; Fontana, L.; Young, L.; Coggan, A.R.; Kilo, C.; Patterson, B.W.; Mohammed, S. Absence of an effect of liposuction on insulin action and risk factors for coronary heart disease. N. Engl. J. Med. 2004, 350, 2549-2557. [CrossRef] [PubMed]

8. Thörne, A.; Lönnqvist, F.; Apelman, J.; Hellers, G.; Arner, P. A pilot study of long-term effects of a novel obesity treatment: Omentectomy in connection with adjustable gastric banding. Int. J. Obes. 2002, 26, 193-199. [CrossRef] [PubMed]

9. Ameer, F.; Scandiuzzi, L.; Hasnain, S.; Kalbacher, H.; Zaidi, N. De novo lipogenesis in health and disease. Metabolism 2014, 63, 895-902. [CrossRef] [PubMed]

10. Diraison, F.; Dusserre, E.; Vidal, H.; Sothier, M.; Beylot, M. Increased hepatic lipogenesis but decreased expression of lipogenic gene in adipose tissue in human obesity. Am. J. Physiol. Endocrinol. Metab. 2002, 282, 46-51.

11. Letexier, D.; Pinteur, C.; Large, V.; Fréring, V.; Beylot, M. Comparison of the expression and activity of the lipogenic pathway in human and rat adipose tissue. J. Lipid Res. 2003, 44, 2127-2134. [CrossRef] [PubMed]

12. Minehira, K.; Vega, N.; Vidal, H.; Acheson, K.; Tappy, L. Effect of carbohydrate overfeeding on whole body macronutrient metabolism and expression of lipogenic enzymes in adipose tissue of lean and overweight humans. Int. J. Obes. Relat. Metab. Disord. 2004, 28, 1291-1298. [CrossRef] [PubMed]

13. Hudgins, L.C.; Baday, A.; Hellerstein, M.K.; Parker, T.S.; Levine, D.M.; Seidman, C.E.; Neese, R.A.; Tremaroli, J.D.; Hirsch, J. The effect of dietary carbohydrate on the genes for fatty acid synthase and inflammatory cytokines in adipose tissue from lean and obese subjects. J. Nutr. Biochem. 2008, 19, 237-245. [CrossRef] [PubMed]

14. Ranganathan, G.; Unal, R.; Pokrovskaya, I.; Yao-Borengasser, A.; Phanavanh, B.; Lecka-Czernik, B.; Rasouli, N.; Kern, P.A. The lipogenic enzymes DGAT1, FAS, and LPL in adipose tissue: Effects of obesity, insulin resistance, and TZD treatment. J. Lipid Res. 2007, 47, 2444-2450. [CrossRef] [PubMed] 
15. Tinahones, F.J.; Garrido-Sanchez, L.; Miranda, M.; García-Almeida, J.M.; Macias-Gonzalez, M.; Ceperuelo, V.; Gluckmann, E.; Rivas-Marin, J.; Vendrell, J.; García-Fuentes, E. Obesity and insulin resistance-related changes in the expression of lipogenic and lipolytic genes in morbidly obese subjects. Obes. Surg. 2010, 20, 1559-1567. [CrossRef] [PubMed]

16. Goto, T.; Lee, J.Y.; Teraminami, A.; Kim, Y.I.; Hirai, S.; Uemura, T.; Inoue, H.; Takahashi, N.; Kawada, T. Activation of peroxisome proliferator-activated receptor-alpha stimulates both differentiation and fatty acid oxidation in adipocytes. J. Lipid Res. 2011, 52, 873-884. [CrossRef] [PubMed]

17. Lee, J.Y.; Hashizaki, H.; Goto, T.; Sakamoto, T.; Takahashi, N.; Kawada, T. Activation of peroxisome proliferator-activated receptor- $\alpha$ enhances fatty acid oxidation in human adipocytes. Biochem. Biophys. Res. Commun. 2011, 407, 818-822. [CrossRef] [PubMed]

18. Wang, Y.; Lee, C.; Tiep, S.; Yu, R.T.; Ham, J.; Kang, H.; Evans, R.M.; Jolla, L. Peroxisome-proliferator-activated receptor d activates fat metabolism to prevent obesity. Cell 2003, 113, 159-170. [CrossRef]

19. Auguet, T.; Guiu-Jurado, E.; Berlanga, A.; Terra, X.; Martinez, S.; Porras, J.A.; Ceausu, A.; Sabench, F.; Hernandez, M.; Aguilar, C.; et al. Downregulation of lipogenesis and fatty acid oxidation in the subcutaneous adipose tissue of morbidly obese women. Obesity (Silver Spring) 2014, 22, 2032-2038. [CrossRef] [PubMed]

20. Dahlman, I.; Linder, K.; Nordstrom, E.A.; Andersson, I.; Liden, J.; Verdich, C.; Sorensen, T.; Arner, P. Changes in adipose tissue gene expression with energy restricted diets in obese women. Am. J. Clin. Nutr. 2005, 81, 1275-1285. [PubMed]

21. Dolinková, M.; Dostálová, I.; Lacinová, Z.; Michalský, D.; Haluzíková, D.; Mráz, M.; Kasalický, M.; Haluzík, M. The endocrine profile of subcutaneous and visceral adipose tissue of obese patients. Mol. Cell. Endocrinol. 2008, 291, 63-70. [CrossRef] [PubMed]

22. Ortega, F.J.; Mayas, D.; Moreno-Navarrete, J.M.; Catalán, V.; Gómez-Ambrosi, J.; Esteve, E.; Rodriguez-Hermosa, J.I.; Ruiz, B.; Ricart, W.; Peral, B.; et al. The gene expression of the main lipogenic enzymes is downregulated in visceral adipose tissue of obese subjects. Obesity (Silver Spring) 2009, 18, 13-20. [CrossRef] [PubMed]

23. Fernández-Galilea, M.; Pérez-Matute, P.; Prieto-Hontoria, P.L.; Sáinz, N.; López-Yoldi, M.; Houssier, M.; Martínez, J.A.; Langin, D.; Moreno-Aliaga, M.J. A lipoic acid reduces fatty acid esterification and lipogenesis in adipocytes from overweight/obese subjects. Obesity 2014, 22, 2210-2215. [CrossRef] [PubMed]

24. Lodhi, I.J.; Yin, L.; Jensen-urstad, A.P.L.; Funai, K.; Coleman, T.; Baird, H.; Ramahi, M.K.; Razani, B.; Song, H.; Fu-hsu, F.; et al. Inhibiting adipose tissue lipogenesis reprograms thermogenesis and PPAR $\gamma$ activation to decrease diet-induced obesity. Cell Metab. 2013, 16, 189-201. [CrossRef] [PubMed]

25. Mardinoglu, A.; Kampf, C.; Asplund, A.; Fagerberg, L.; Hallstro, M.; Edlund, K.; Blu, M.; Ponte, F.; Uhlen, M.; Nielsen, J. Defining the human adipose tissue proteome to reveal metabolic alterations in obesity. J. Proteome Res. 2014, 13, 5106-5119. [CrossRef] [PubMed]

26. MacLaren, R.E.; Cui, W.; Lu, H.; Simard, S.; Cianflone, K. Association of adipocyte genes with ASP expression: A microarray analysis of subcutaneous and omental adipose tissue in morbidly obese subjects. BMC Med. Genom. 2010, 3, 3. [CrossRef] [PubMed]

27. Ebbert, J.; Jensen, M. Fat depots, free fatty acids, and dyslipidemia. Nutrients 2013, 5, 498-508. [CrossRef] [PubMed]

28. Klöting, N.; Blüher, M. Adipocyte dysfunction, inflammation and metabolic syndrome. Rev. Endocr. Metab. Disord. 2014, 15, 277-287. [CrossRef] [PubMed]

29. Després, J.P.; Lemieux, I. Abdominal obesity and metabolic syndrome. Nature 2006, 444, 881-887. [CrossRef] [PubMed]

30. Kotronen, A.; Yki-Järvinen, H.; Sevastianova, K.; Bergholm, R.; Hakkarainen, A.; Pietiläinen, K.H.; Juurinen, L.; Lundbom, N.; Sørensen, T.I. Comparison of the relative contributions of intra-abdominal and liver fat to components of the metabolic syndrome. Obesity (Silver Spring) 2011, 19, 23-28. [CrossRef] [PubMed] 
31. Savage, D.B.; Tan, G.D.; Acerini, C.L.; Jebb, S.A.; Agostini, M.; Gurnell, M.; Williams, R.L.; Umpleby, A.M.; Thomas, E.L.; Bell, J.D.; et al. Human metabolic syndrome resulting from dominant-negative mutations in the nuclear receptor peroxisome proliferator-activated receptor- $\gamma$. Diabetes 2003, 52, 910-917. [CrossRef] [PubMed]

32. Macfarlane, D.P.; Forbes, S.; Walker, B.R. Glucocorticoids and fatty acid metabolism in humans: Fuelling fat redistribution in the metabolic syndrome. J. Endocrinol. 2008, 197, 189-204. [CrossRef] [PubMed]

33. Yim, J.E.; Heshka, S.; Albu, J.B.; Heymsfield, S.; Gallagher, D. Femoral-gluteal subcutaneous and intermuscular adipose tissues have independent and opposing relationships with CVD risk. J. Appl. Physiol. 2008, 104, 700-707. [CrossRef] [PubMed]

34. Snijder, M.B.; Dekker, J.M.; Visser, M.; Yudkin, J.S.; Stehouwer, C.D.A.; Bouter, L.M.; Heine, R.J.; Nijpels, G.; Seidell, J.C.; Coen, D.A.; et al. Larger thigh and hip circumferences are associated with better glucose tolerance: The hoorn study. Obes. Res. 2003, 11, 104-110. [CrossRef] [PubMed]

35. Snijder, M.B.; Dekker, J.M.; Visser, M.; Bouter, L.M.; Stehouwer, C.D.A.; Yudkin, J.S.; Heine, R.J.; Nijpels, G.; Seidell, J.C. Trunk fat and leg fat have independent and opposite associations with fasting and postload glucose levels: The Hoorn study. Diabetes Care 2004, 27, 372-377. [CrossRef] [PubMed]

36. Pelt, R.E.V.A.N.; Evans, E.M.; Schechtman, K.B.; Ehsani, A.A.; Kohrt, W.M.; Contributions, W.M.K. Contributions of total and regional fat mass to risk for cardiovascular disease in older women. Am. J. Physiol. Endocrinol. Metab. 2002, 282, 1023-1028. [CrossRef] [PubMed]

37. Kim, J.K.; Gavrilova, O.; Chen, Y.; Reitman, M.L.; Shulman, G.I. Mechanism of insulin resistance in A-ZIP/F-1 fatless mice. J. Biol. Chem. 2000, 275, 8456-8460. [CrossRef] [PubMed]

38. Huang-Doran, I.; Sleigh, A.; Rochford, J.J.; O’Rahilly, S.; Savage, D.B. Lipodystrophy: Metabolic insights from a rare disorder. J. Endocrinol. 2010, 207, 245-255. [CrossRef] [PubMed]

39. Foster, M.T.; Softic, S.; Caldwell, J.; Kohli, R.; DeKloet, A.D.; Seeley, R.J. Subcutaneous adipose tissue transplantation in diet-induced obese mice attenuates metabolic dysregulation while removal exacerbates it. Physiol. Rep. 2013, 1, e00015. [CrossRef] [PubMed]

40. Virtue, S.; Vidal-Puig, A. It's not how fat you are, it's what you do with it that counts. PLoS Biol. 2008, 6, e237. [CrossRef] [PubMed]

41. Geer, E.B.; Shen, W. Gender differences in insulin resistance, body composition, and energy balance. Gend. Med. 2009, 6, 60-75. [CrossRef] [PubMed]

42. Karastergiou, K.; Smith, S.R.; Greenberg, A.S.; Fried, S.K. Sex differences in human adipose tissues-The biology of pear shape. Biol. Sex Differ. 2012, 3, 13. [CrossRef] [PubMed]

43. Varlamov, O.; Bethea, C.L.; Roberts, C.T. Sex-specific differences in lipid and glucose metabolism. Front. Endocrinol. (Lausanne) 2015, 5, 1-7. [CrossRef] [PubMed]

44. Association, A.D. Classification and diagnosis of diabetes. Diabetes Care 2015, 38, S8-S16. [CrossRef] [PubMed]

45. Terra, X.; Auguet, T.; Broch, M.; Sabench, F.; Hernández, M.; Pastor, R.M.; Quesada, I.M.; Luna, A.; Aguilar, C.; del Castillo, D.; et al. Retinol binding protein-4 circulating levels were higher in nonalcoholic fatty liver disease $v s$. histologically normal liver from morbidly obese women. Obesity 2013, 21, 170-177. [CrossRef] [PubMed]

(C) 2015 by the authors; licensee MDPI, Basel, Switzerland. This article is an open access article distributed under the terms and conditions of the Creative Commons by Attribution (CC-BY) license (http:/ / creativecommons.org/licenses/by/4.0/). 